white. Primaries consisting of two distinct, uniform colours. The lower and larger area, starting upward from bulge near base in an outwardly curved line, and rounding off sharply at apex, is a field of chestnutbrown. The rest, from below base rounding upward, running parallel with costa to apex and including half of discal cell, is a costal field of bright yellow. Secondaries light yellow, fading into white along anal margin and near basal area. Brown exterior marginal line. Fringes light yellow.

Below: Abdomen yellowish-white. Primaries and secondaries yellowish-white with a decided metallic sheen. A narrow strip of bright yellow along costa of primaries, and in the centre of same a broad brown dash triangularly formed and pointing towards base. Fringes prominently brown.

Expanse of wings, $22 \mathrm{~mm}$; length of body, $5 \mathrm{~mm}$.

Habitat: Houston, Texas. Type, $q$. Coll. B. Neumoegen.

This beautiful Feliothid is unlike any other of our fauna, both in shape of wings and odd markings. It comes, apparently, near the genus Schinia, Hb.

\title{
A NEW BUTTERFLY FROM LOWER CALIFORNIA.
}

BY A. G. WEEKS, JR., BOSTON, MASS.

Pyrgus pelagica, n. sp.

Habitat: San José del Cabo, Lower California.

Expanse, 1.25 inches.

Description.-Under side of palpi and head covered with whitish hairs; top of same blackish-brown gray ; forehead with some whitish hairs mixed with the darker. Thorax and abdomen blackish above, end of abdomen shading into gray, beneath whitish. Legs covered with whitish hairs, brownish at ends. Antenna blackish, with small white annulations at base of each joint; club above blackish, tipped with light brown, below light brown down to joint. Wings above dark-brownish gray, with white and grayish-white spots, hind margins with a fringe of dark brownish-gray. Hind margin of forewings edged with a dark line, just within which, in interspaces, is a row of indistinct darkish spots, absent in some specimens. The dark brownish-gray covers marginal 
area, and is dusted and irregulary shaded with grayish scales. On costa one-fourth distance from tip to base, between the subcostal nervules, three (sometimes two or one) small white spots. Across centre of wing, extending from edge of costa across end of discoidal cell down to submedian nervule, a whitish band of consecutive spots, of irregular form and varying distinctness, sprinkled more or less with brownish scales. In some specimens this space shades off into ground colour, in others the edges between spots and ground colour are distinctly marked, and bordered with a darkish line. In centre of cell, an irregular whitish spot of same character; between this spot and the spot at end of cell, and below submedian nervule, an irregular whitish spot, dusted more with brownish scales. Base dark brownish-gray, with some grayish scales. The suffusion of the ground colour is more marked in some specimens than others, rendering an accurate general limitation of the spots difficult. Some specimens show a slight yellowish tinge on white spots. Ground colour of hindwings a blackish-brown, of more distinct character than the ground colour of forewings. Costa white. Hind margin edged with a dark line, within which, in interspaces, is a row of white specks, sometimes absent, which, at anal angle, are transversely elongated, forming an indistinct line from inner margin to submedian nervule. Within these, one-third distance to base, a row of brownish spots, extending from costa to inner margin, parallel to hind margin, but not in line, and the one near centre larger than the others, and drawn nearer to cell. Within these, across centre of wing, a prominent whitish band, forming an extension of the same on forewing, but of purer white, ending at submedian nervure. Basal area of ground colour, but toward inner margin, covered with light grayish hairs, which extend along margin to anal angle. Beneath general colour is grayish-white, with a very slight yellowish-brown tinge, and showing shadows of the markings above. Costa of forewing marked with darkish-brown and white, reflecting markings above. Hind margin edged with blackish-brown, and within, covering one-third of marginal area, darkish-brown, with a row of white specks in interspaces. Costa of hindwing white, same as ground colour. Hind margin edged with $\dot{a}$ line of blackish-brown, shading off into ground colour. In space below submedian nervule, the dark markings of upper side show more prominently than elsewhere.

Described from twelve specimens in my collection, taken near San José del Cabo, in Lower California, by Mr. M. Abbot Frasar, I 888. 